\title{
Prototype Autonomous Rover Pembersih Sampah Pantai menggunakan ArduPilot
}

\author{
Adhy Febry Anto ${ }^{1}$, Totok Sukardiyono ${ }^{2}$ \\ 1,2Program Studi Teknik Elektronika Fakultas Teknik Universitas Negeri Yogyakarta \\ E-mail: adhy.febry2016@student.uny.ac.id
}

\begin{abstract}
Indonesia has the second longest coastline in the world. On the other hand, Indonesia is the second largest contributor to marine waste in the world. Coastal cleanliness needs to be maintained so that it becomes an attraction for tourism and to protect the marine ecosystem. This article describes the results of testing devices that can be used to clean beaches. Research carried out by the development method. An autonomous beach garbage cleaning rover is a beach trash sweeper robot equipped with GPS, compass, telemetry, ArduPilot as a navigation and communication system when the robot operates. This robot moves using 2 DC motors with torque of $\pm 4 \mathrm{~kg}$. The robot is also equipped with a conveyor that functions to sweep plastic debris on the beach. The test results show that the robot can go according to the specified path, according to the coordinates entered (100\% accuracy) and be able to transport plastic waste. This is because the motor used has a small torque, so it is not able to lift large objects. The next robot development can be done in terms of: identifying the capacity of robots to accommodate various types of waste, testing the ability of robots to clean waste, the use of solar cells, and trajectory management systems.
\end{abstract}

Keywords: ArduPilot, beach plastic waste, autonomous rover

\begin{abstract}
ABSTRAK
Indonesia memiliki garis pantai terpanjang kedua di dunia. Dilain pihak, Indonesia merupakan penyumbang sampah laut terbanyak kedua didunia. Pesisir pantai perlu dijaga kebersihannya agar menjadi daya tarik pariwisata dan untuk menjaga ekosistem laut. Artikel ini memaparkan hasil pengujian perangkat yang dapat digunakan untuk membersihkan pantai. Penelitian dilakukan dengan metode pengembangan. Autonomous rover pembersih sampah pantai merupakan robot penyapu sampah pantai yang dibekali dengan GPS, kompas, telemetri, ArduPilot sebagai sistem navigasi dan komunikasi saat robot beroperasi. Robot ini bergerak menggunakan 2 motor DC dengan torsi $\pm 4 \mathrm{Kg}$. Robot juga dibekali dengan konveyor yang berfungsi untuk menyapu sampah-sampah plastik yang ada di pantai. Hasil pengujian menunjukkan bahwa robot dapat melaju sesuai dengan jalur yang ditentukan, sesuai koordinat yang dimasukan (akurasi 100\%) dan mampu mengangkut sampah plastik. Hal ini dikarenakan motor yang digunakan memiliki torsi kecil, sehingga tidak mampu mengangkat benda besar. Pengembangan robot berikutnya dapat dilakukan dalam hal: identifikasi kapasitas robot dalam menampung berbagai jenis sampah, uji coba kemampuan robot dalam melakukan pembersihan sampah, penggunaan sel surya, dan sistem manajemen lintasan.
\end{abstract}

Kata kunci: ArduPilot, sampah plastik pantai, autonomous rover

\section{PENDAHULUAN}

Indonesia merupakan Negara Kelautan.

Beberapa informasi mengenai kelautan Indonesia adalah: (1) Indonesia memiliki pulau sebanyak 17.504, sehingga merupakan Negara kepulauan terbesar di dunia; (2) Indonesia memiliki garis pantai sepanjang $95.181 \mathrm{~km}$ yang merupakan garis pantai terpanjang kedua di dunia; dan (3) dan memiliki luas perairan laut mencapai 5,8 juta kilometer persegi, yang merupakan $71 \%$ dari keseluruhan wilayah Indonesia, sehingga Indonesia merupakan negara maritime [1]. Hasil laut serta pesona 
bahari yang dimiliki Indonesia tentu mempunyai kekayaan yang luar biasa di sektor kelautan. Bahkan terumbu karang di Indonesia menyumbang $18 \%$ dari luas total terumbu karang di dunia dan $65 \%$ laut total coral triangle, luas terumbu karang di perairan Nusantara sebesar $50.875 \mathrm{~km} 2$ yang sebagian besar terumbu karang indah ada di bagian timur Indonesia [2]. Banyak area laut Indonesia yang menjadi daya tarik pariwisata. Pesisir pantai merupakan salah satu daya tarik pariwisata di Indonesia. Kebersihan pantai perlu dijaga. Selain untuk mempertahankan pantai sebagai daya tarik pariwisata, juga untuk menjaga ekosistem laut.

Indonesia merupakan penyumbang sampah laut terbanyak kedua setelah Tiongkok, dimana sampah plastik yang dihasilkan Indonesia sebesar 187,2 juta ton [3]. Dampak dari banyaknya sampah di perairan Indonesia akan menyebabkan terganggungnya ekosistem laut seperti rusaknya terumbu karang, penurunan spesies endemik maupun spesies langka yang hanya ada di laut Indonesia akan mengalami kepunahan, hasil laut yang berkurang serta merusak pesona Indonesia dengan adanya sampah di pantai. Sampah yang mengapung juga membuat pemandangan pantai terganggu karena sampah yang tidak bisa terurai menggunung sepanjang bibir pantai. Faktor tersebut yang membuat wisatawan domestik maupun wisatawan asing berkurang untuk menikmati indahnya pantai di Indonesia. Hal tersebut seperti yang dinyatakan oleh Widyowati, Syaputri dan Febrianto, bahwa sampah menyebabkan daya tarik wisata Bali menurun dan dapat membahayakan kehidupan laut [4]. Lebih khusus lagi terkait sampah plastik, dimana menurunnya kunjungan wisata dikarenakan banyaknya sampah plastik [5]. Oleh karena itu, diperlukan adanya upaya untuk menjaga kebersihan pantai.

Upaya yang dapat dilakukan pemerintah untuk saat ini sudah menunjukkan kepedulian terhadap pencemaran sampah yang terbuang di laut Indonesia. Namun, pembersihan sampah di pesisir pantai masih menggunakan cara manual dengan cara memunggut atau menyapu sampah. Hal tersebut dilakukan baik oleh petugas kebersihan maupun partisipasi masyarakat. Akan tetapi ditemukan kasus dimana terdapat petugas kebersihan kurang disiplin dalam bertugas dan masyarakat pasif dalam berpartisipasi menjaga kebersihan [6]. Dilain pihak, pembersihan secara manual membutuhkan waktu yang lama agar pantai kembali menjadi bersih. Oleh karena itu, dibutuhkan alat bantu yang daat membantu melakukan pembersihan atau pengambilan sampah dipantai.

Beberapa penelitian terkait perangkat yang dapat mengumpulkan sampah dipantai, misalnya Beach Cleaning Trailer sebagai pembersih sampah pantai dengan sistem hidrolik [7]. Garbage Collection Robot merupakan perangkat mampu mengumpulkan sampah melalui komunikasi nirkabel dan beroperasi ramah lingkungan melalui penggunaan sel surya [8]. Perangkat lainnya adalah garbage collector bertenaga sel surya [9]. Perangkat tersebut belum automatis secara penuh. Kemudian terdapat perancangan eco beach cleaner yang dapat melintasi medan pasir dan mengambil sampah-sampah berukuran kecil [10]. Perangkat pembersih sampah lainnya didesain dengan meminimalisir kontak dengan petugas kebersihan secara langsung [11].

Dilain pihak terdapat perangkat lunak navigasi berbasis open source bernama ArduPilot. ArduPilot memungkinkan pengembangan sistem keandaraan tak berawak yang terpercaya secara otonom, misalya untuk drone multirotor, fixed-wing dan VTOL aircraft, helikopter, ground rovers, kapal, kapal selam dan pelacak antena. ArduPilot firmware dapat bekerja pada mikrokontroler. Ground Control Station (GCS) merupakan perangkat lunak yang digunakan sebagai antarmuka dengan pengendali untuk mengatur, mengkonfigurasi, menguji, dan menyetel kendaraan [12]. Mission Planner adalah GCS berfitur lengkap yang 
didukung oleh ArduPilot. Mission Planner merupakan stasiun pengendali darat untuk plane, copter dan rover yang hanya kompatibel dengan Windows [13]. Ardupilot Mega 2.6 (APM 2.6) merupakan modul autopilot open source yang digunakan dalam penelitian ini. Gambar 1 merupakan modul APM 2.6.

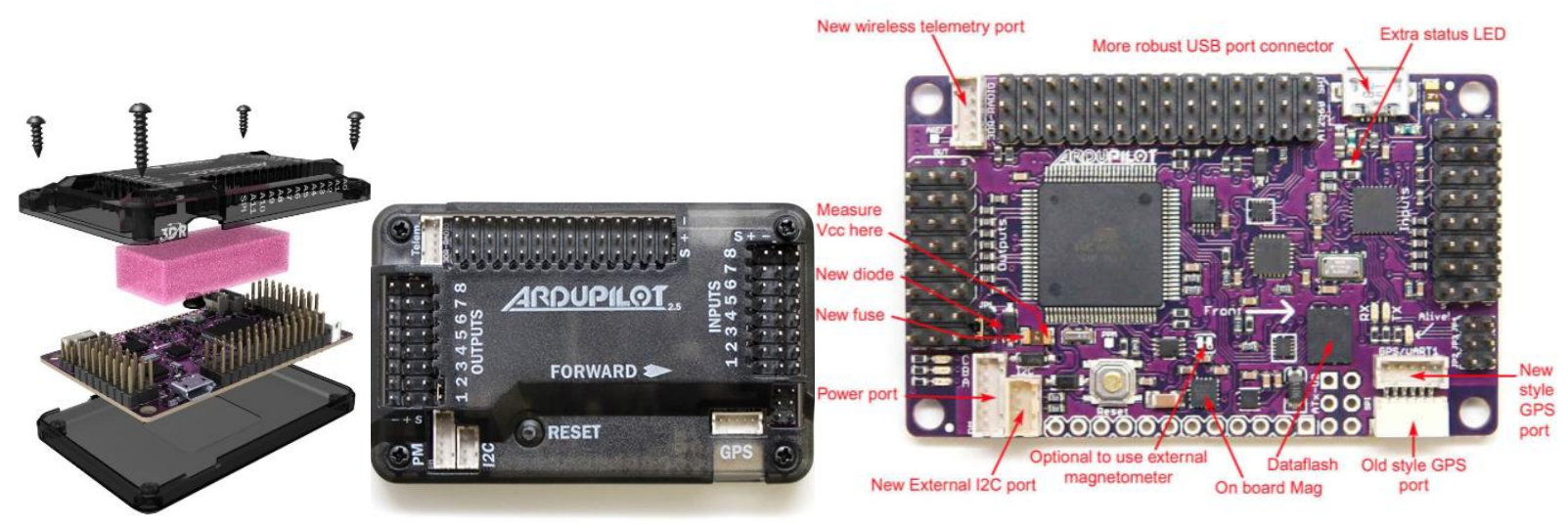

Gambar 1. APM 2.6 [14]

ArduPilot telah digunakan untuk memetakan dan memantau lingkungan laut di daerah dangkal [15]. Berpijak dari beberapa hal tersebut, penelitian ini bertujuan untuk mengembangkan sebuah perangkat yang dapat digunakan untuk mengambil sampah pantai secara otomatis. Keunggulan dari perangkat yang dikembangkan peneliti dengan perangkat sejenis pada penelitian sebelumnya adalah mengenai metode kendalinya melalui pemanfaatan sistem navigasi berbasis ArduPilot. Desain alat ini mempermudah dalam pengambilan sampah di pantai dengan hanya mengontrol jalannya sistem yang akan berjalan sendiri sesuai dengan rute yang di tentukan.

\section{METODE}

Autonomous rover pembersih sampah pantai merupakan robot penyapu sampah pantai untuk bidang sosial dan maritim, robot dibekali dengan GPS, kompas, telemetri, sebagai sistem navigasi dan komunikasi saat robot beroperasi. Penelitian menggunakan model pengembangan yang terdiri atas beberapa langkah, diantaranya: (1) identifikasi dan analisis kebutuhan komponen; (2) perancangan; (3) implementasi; dan (4) pengujian. Identifikasi kebutuhan bertujuan untuk menentukan kebutuhan komponen yang diperlukan dalam pembuatan. Analisis yang mendalam akan menghasilkan desain sesuai kebutuhan [16]. Berdasarkan kebutuhan, deskripsi perangkat yang dikembangkan adalah berupa robot mobil untuk bidang sosial dan maritim dengan kendali jarak jauh. Robot ini bergerak menggunakan 2 motor DC dengan torsi $\pm 4 \mathrm{Kg}$. Robot juga dibekali dengan konveyor yang berfungsi untuk menyapu sampah-sampah plastik yang ada di pantai. Identifikasi kebutuhan disajikan pada Tabel 1 . Kebutuhan komponen pada pengembangan perangkat robot pembersih pantai ini terdiri untuk pemenuhan fungsi catu daya, input, proses dan masukan.

Tabel 1. Identifikasi Kebutuhan

\begin{tabular}{llc}
\hline Fungsi & \multicolumn{1}{c}{ Komponen } & Spesifikasi \\
\hline Catu & Baterai Li-Po & 4 cell, $1600 \mathrm{mAh}$ \\
daya & Baterai Li-Po & 2 cell, $1000 \mathrm{mAh}$ \\
& DC-DC step Down & XL4005 \\
Input & Telemetri & Frekuensi 433 MHz \\
& GPS & NEO UBLOX \\
& TX/RX & $2,4 \mathrm{GHz}$ \\
Proses & Pengendali & APM 2.6 \\
& ESC & DC 20A \\
& Aplikasi & Mission Planner \\
Keluaran & Motor DC & $\pm 4 \mathrm{Kg}$ \\
& Motor DC & $\pm 10 \mathrm{Kg}$ \\
& Buzzer & $5 \mathrm{~V}$ \\
& Receiver & ROTG \\
\hline
\end{tabular}


Proses rancang bangun alat Autonomous Rover Pembersih Sampah Pantai ini diawali dengan dan dilanjutkan melalui beberapa tahap perancangan seperti, perancangan sistem, perancangan komponen, dan perancangan mekanik. Perancangan tersebut dilakukan menggunakan beberapa perangkat lunak simulasi yang ditujukan agar ketika diimplementasikan dapat meminimalisir kesalahan baik sistem maupun mekanik. Alasan lain tahapan perancangan adalah untuk menekan pembengkakan biaya. Blok diagram sistem keseluruhan dari robot terdiri dari tiga blok yang meliputi: blok input, blok proses, dan blok output. Blok diagram ditampilkan pada Gambar 2. Setelah perancangan dilakukan, maka implementasi dilakukan, baik dari sistem, komponen, maupun mekanik sehingga menjadi sebuah kesatuan alat yang baik. Tahapan pengembangan terakhir adalah pengujian yang digunakan untuk untuk mengatahui kinerja dari alat.

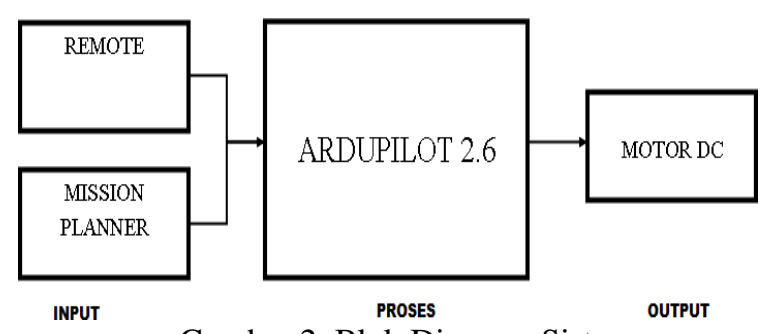

Gambar 2. Blok Diagram Sistem

\section{HASIL DAN PEMBAHASAN}

Perancangan robot terdiri atas perancangan hardware dan software. Perancangan hardware dibagi menjadi dua bagian, yaitu desain mekanik dan elektronik. Rancangan kerangka diperlukan untuk membangun mekanik robot dengan ukuran dan dudukan komponen agar dapat presisi dan pergerakan robot dapat berjalan sempurna tanpa mengalami kendala. Rancangan kerangka yang telah dibuat kemudian di potong menggunakan mesin pemotong laser. Gambar 3 merupakan rancangan mekanik utama robot. Rancangan 3D diperlukan sebagai acuan dalam membangun suatu alat, dalam hal ini robot autonomous rover pembersih sampah pantai. Terdapat beberapa part untuk kerangka robot dan part untuk konveyor yang kemudian dilakukan assembly menjadi satu kesatuan mekanik. Gambar 4 merupakan rancangan 3D robot.

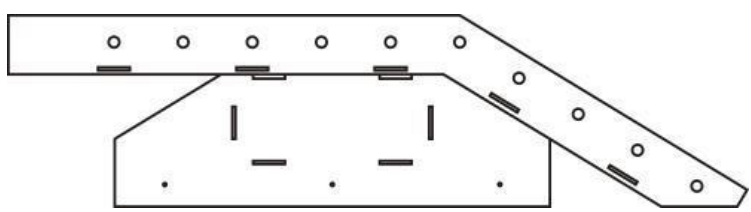

Gambar 3. Mekanik Utama Robot

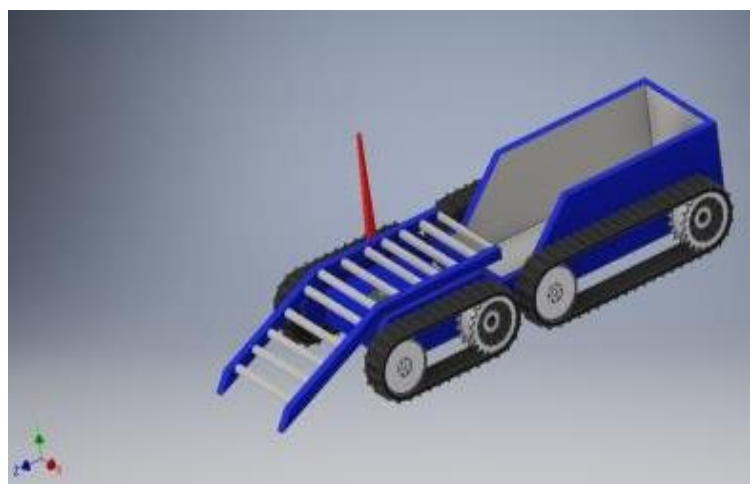

Gambar 4. Rancangan 3D Robot

Sistem elektronik autonomous rover pembersih sampah pantai terdiri dari beberapa komponen, Ardupilot, Remote Control, ESC 20A, motor DC, GPS, Telemetri. Berikut desain dari rangkaian elektronik menggunakan perangkat lunak Proteus. Skema rangkaian dari robot ini ditampilkan pada Gambar 5.

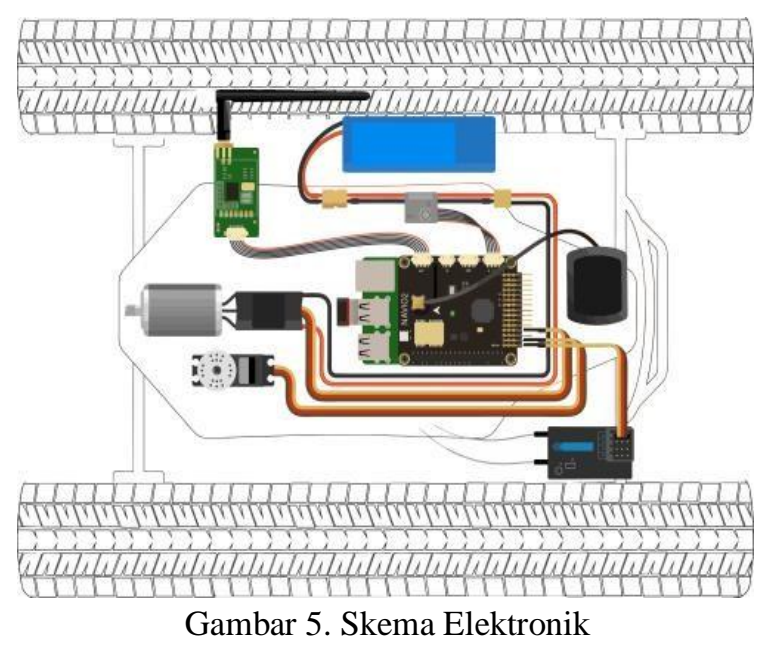


Perancangan software merupakan pembuatan sistem dengan membuat listing program yang akan dimasukkan ke dalam chip ATMega256 Ardupilot 2.6. Pada tahap perancangan, perangkat lunak yang digunakan adalah Mission Planner. Gambar 6 menunjukkan tampilan pada aplikasi Mission Planner.

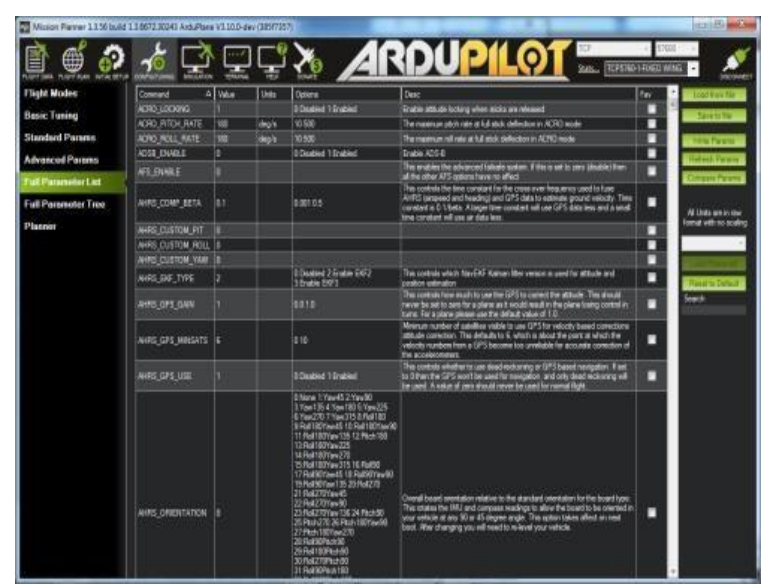

Gambar 6. Software Mission Planner

Pengujian terdiri atas pengujian fungsional dan pengujian unjuk kerja. Pengujian fungsional dilakukan dengan cara menguji setiap rangkaian berdasarkan karakterisitik dan fungsinya masing-masing sesuai dengan rangkaian dan perangkat lunak yang meliputi pengujian tegangan arduino uno R3 dan DC-DC step down, arus pada robot, catu daya, driver motor L298N, motor DC, lengan robot, sensor kompas, lintasan robot, dan kecepatan robot. Pengujian unjuk kerja dilakukan untuk mengetahui bahwa robot beserta sistem dapat bekerja dengan baik secara keseluruhan. Tabel 2 dan Tabel 3 merupakan hasil pengujian tegangan.

Tabel 2. Pengujian Tegangan Tanpa Beban

\begin{tabular}{cccccc}
\hline No & Pengukuran & V-Out & $\begin{array}{c}\text { Alat } \\
\text { Ukur }\end{array}$ & Selisih & Error \\
\hline 1. & Ardupilot & $3,3 \mathrm{~V}$ & $3,28 \mathrm{~V}$ & $0,02 \mathrm{~V}$ & $0,6 \%$ \\
& & $5 \mathrm{~V}$ & $5,01 \mathrm{~V}$ & $0,01 \mathrm{~V}$ & $0,2 \%$ \\
2. & DC-DC & $5 \mathrm{~V}$ & $5 \mathrm{~V}$ & $0 \mathrm{~V}$ & $0 \%$ \\
& Step Down & & & & \\
\hline
\end{tabular}

Tabel 3. Pengujian Tegangan dengan Beban

\begin{tabular}{llcccc}
\hline \multirow{2}{*}{ No } & Pengukuran & V-Out & $\begin{array}{c}\text { Alat } \\
\text { Ukur }\end{array}$ & Selisih & Error \\
\hline 1. & Arduino & $3,3 \mathrm{~V}$ & $3,61 \mathrm{~V}$ & $0,31 \mathrm{~V}$ & $9,4 \%$ \\
& Uno R3 & $5 \mathrm{~V}$ & $5,02 \mathrm{~V}$ & $0,02 \mathrm{~V}$ & $0,4 \%$ \\
2. & DC-DC & $5 \mathrm{~V}$ & $5 \mathrm{~V}$ & $0 \mathrm{~V}$ & $0 \%$ \\
& Step Down \\
\hline
\end{tabular}

Pengujian tegangan bertujuan untuk mengetahui perubahan nilai tegangan saat sebelum dan setelah menerima beban pada Ardupilot dan DC-DC Step Down. Hasil data pada Tabel 2 dan Tabel 3 pengujian tanpa beban memiliki persentase error pada pin 3,3V sebesar $0,6 \%$ dan pin $5 \mathrm{~V}$ sebesar $0,2 \%$ Pada DC-DC step down persentase error $0 \%$. Pengujian dengan beban memiliki persentase error pada pin $3,3 \mathrm{~V}$ dan pin $5 \mathrm{~V}$ masing-masing sebesar 9,4\% dan 04\%, serta persentase error DC- DC step down sebesar 0\%. Tabel 4 menunjukkan hasil pengujian data analog terhadap kecepatan motor. Pengujian data analog terhadap kecepatan motor bertujuan untuk mengetahui akurasi data analog yang muncul akibat dinaikannya nozle pada remote kontrol.

Tabel 4. Hasil pengujian data analog terhadap kecepatan motor

\begin{tabular}{cccc}
\hline No. & Data analog & Kecepatan & Kondisi \\
\hline 1 & 1625.00 & $5 \mathrm{~m} / \mathrm{s}$ & Medan beraspal \\
2 & 1625.00 & $5 \mathrm{~m} / \mathrm{s}$ & Medan semen \\
3 & 1625.00 & $5 \mathrm{~m} / \mathrm{s}$ & Medan datar \\
4 & 1625.00 & $5 \mathrm{~m} / \mathrm{s}$ & Medan pasir basah \\
5 & 1625.00 & $5 \mathrm{~m} / \mathrm{s}$ & Medan pasir basah \\
6 & 1625.00 & $5 \mathrm{~m} / \mathrm{s}$ & Medan pasir basah \\
7 & 1500.00 & 0 & Medan pasir kering \\
8 & 1770.00 & $2.2 \mathrm{~m} / \mathrm{s}$ & Medan pasir kering \\
9 & 1930.00 & $3 \mathrm{~m} / \mathrm{s}$ & Medan pasir kering \\
10 & 1770.00 & $2.2 \mathrm{~m} / \mathrm{s}$ & Medan pasir kering \\
\hline
\end{tabular}

Pengujian selanjutnya adalah pengujian GPS terhadap GPS lainya. Pengujian GPS bertujuan untuk mengetahui akurasi dari jalur yang ditunjukan oleh GPS robot, agar tidak terjadi salah arah pada robot. Pengujian ini ditujukan untuk mengetahui akurasi GPS terhadap kordinat yang telah ditentukan juga sebagai alat kalibrasi sehingga data yang di dapat bisa dipertanggung jawabkan, pengujian 
ini dilakukan dengan membuat kordinat yang telah ditentukan kemudian dimasukan pada masing-masing aplikasi dalam hal ini Mission Planner dan Google Maps. Hasil pengujian menunjukkan bahwa robot dapat melaju sesuai dengan jalur yang ditentukan, sesuai koordinat yang dimasukan (akurasi 100\%) dan mampu mengangkut sampah plastik. Hasil pengujian GPS disajikan pada Gambar 7.
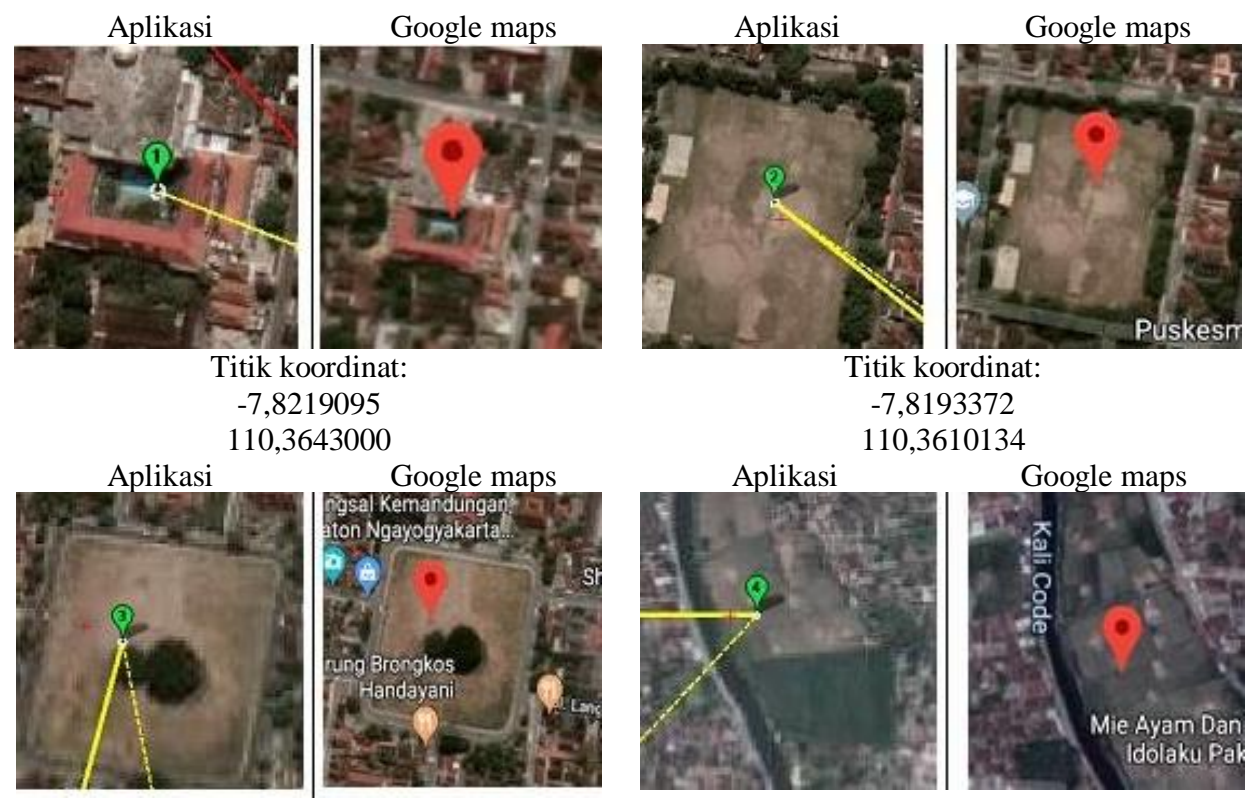

Titik koordinat:

$-7,8117693$

110,3630519

Titik koordinat:

$-78118118$

110,3751111

Gambar 7. Pengujian GPS

Tabel 5. Pengujian Arus pada Robot

Baterai (2s $1000 \mathrm{mAh}) \quad$ Baterai (4s $1600 \mathrm{mAh})$

\begin{tabular}{ccccc} 
No & Kondisi & $\begin{array}{c}\text { Arus } \\
\text { (Ampere) }\end{array}$ & Kondisi & $\begin{array}{c}\text { Arus } \\
\text { (Ampere) }\end{array}$ \\
\hline 1. & Standby & $0,58 \mathrm{~A}$ & Standby & $0,13 \mathrm{~A}$ \\
2. & Motor & $0,45 \mathrm{~A}$ & Motor operasi & $0,47 \mathrm{~A}$ \\
\hline
\end{tabular}

Pengujian selanjutnya adalah pengujian arus pada motor. Tabel 5 menyajikan hasil pengujian arus pada robot. Pengujian arus bertujuan untuk mengetahui berapa arus yang mengalir pada rangkaian untuk mengoperasikan robot. Setelah nilai arus diketahui, selanjutnya dapat menghitung daya tahan baterai berdasarkan jenis baterai dan beban yang diperoleh oleh masing-masing baterai. Dalam hal ini, terdapat dua baterai yang digunakan yaitu $2 \mathrm{~s}$ dan $3 \mathrm{~s}$ dengan perhitungan yang tersaji pada Tabel 6.

Tabel 6. Perhitungan daya tahan baterai

\begin{tabular}{lclll}
\hline Baterai & Tegangan & \multirow{2}{*}{ Baterai } & \multicolumn{1}{c}{ Sumber daya baterai } & \multicolumn{2}{c}{ Arus standby } \\
Baterai 2s 8,4 VKapasitas $1 \mathrm{Ah}$ & $=\mathrm{V} \times$ Kapasitas Batt & $=0,58 \mathrm{~A} \times 8,4 \mathrm{~V}$ & $=8,4 \mathrm{Wh} / 4,872 \mathrm{~W}$ \\
& & $=8,4 \mathrm{~V} \times 1 \mathrm{Ah}=8,4 \mathrm{Wh}$ & $=4,872 \mathrm{~W}$ & $=1,72 \mathrm{jam}$ \\
Baterai 3s 12,6 VKapasitas $1,8 \mathrm{Ah}$ & $=\mathrm{V} \times$ Kapasitas Batt & $=0,13 \mathrm{~A} \times 12,6 \mathrm{~V}=22,68 \mathrm{Wh} / 1,638 \mathrm{~W}$ \\
& $=12,6 \mathrm{~V} \times 1,8 \mathrm{Ah}=22,68 \mathrm{Wh}$ & $=4,872 \mathrm{~W}$ & $=13,85 \mathrm{jam}$ \\
\hline
\end{tabular}

Berdasarkan hasil perhitungan pada Tabel 6, dapat diketahui secara teori bahwa daya tahan baterai $2 \mathrm{~s}$ dan baterai $3 \mathrm{~s}$ bervariasi tergantung dari kondisi robot beroperasi. Hal tersebut bisa dijadikan sebagai acuan tentang berapa lama daya tahan baterai untuk mengoperasikan robot. Dari berbagai hasil pengujian, dapat dinyatakan bahwa robot ini secara elektronis, melalui 
pengujian tegangan, pengujian kecepatan motor terhadap berbagai kondisi dataran, pengujian GPS, dan pengujian arus menunjukkan bahwa robot dapat digunakan untuk memantau dan melakukan pembersihan sampah di pantai. Berdasarkan pengujian yang telah dilakukan alat ini dapat melaju sesuai dengan jalur yang ditentukan, hal ini dilihat dari kordinat yang dimasukan sama dengan akurasi $100 \%$ selain itu alat ini mengangkut sampah yang berjenis plastik. Hal ini dikarenakan motor yang digunakan memiliki torsi yang kecil sehingga tidak mampu mengangkat benda dengan berat yang besar.

Untuk penelitian selanjutnya perlu dilakukan uji coba kemampuan robot dalam melakukan pembersihan sampah. Beberapa hal yang mungkin perlu diperhatikan adalah kapasitas robot dalam menampung sampah dan jenis-jenis sampah apa saja yang dapat diambil oleh robot. Robot ini masih dalam bentuk prototipe, sehingga masih perlu dilakukan pengembangan lebih lanjut. Pengembangan perangkat pembersih sampah pantai sebelumnya telah menggunakan sel surya [8] [9]. Oleh karena itu, pengembangan ke depan juga perlu mempertimbangkan hal tersebut. Sebagai tambahan, sistem manajemen lintasan (trajectory management system) memungkinkan kendaraan tidak berawak untuk beradaptasi dengan sekitarnya secara realtime dan dapat menambahkan sensor sebanyak yang dibutuhkan untuk aplikasi [17]. Sistem tersebut dapat diaplikasikan untuk perangkat pembersih sampah di pantai berikutnya.

\section{SIMPULAN}

Indonesia merupakan Negara Maritim memiliki garis pantai sepanjang $95.181 \mathrm{~km}$ yang merupakan garis pantai terpanjang kedua di dunia. Dilain pihak, Indonesia merupakan penyumbang sampah laut terbanyak kedua didunia, dimana sampah plastik yang dihasilkan Indonesia sebesar 187,2 juta ton. Pesisir pantai perlu dijaga kebersihannya, selain sebagai daya tarik pariwisata, juga untuk menjaga ekosistem laut. Hasil pengembangan diantaranya adalah: (1) robot yang dikembangkan adalah sebuah perangkat pembersih sampah pantai yang dapat membersihkan sampah pantai secara autonom. Robot dibekali dengan GPS, kompas, telemetri, Ardupilot sebagai sistem navigasi dan komunikasi saat robot beroperasi. Robot ini bergerak menggunakan 2 motor DC dengan torsi $\pm 4 \mathrm{Kg}$. Robot juga dibekali dengan konveyor yang berfungsi untuk menyapu sampah-sampah plastik yang ada di pantai; dan (2) dari berbagai hasil pengujian, dapat dinyatakan bahwa robot ini secara elektronis, melalui pengujian tegangan, pengujian kecepatan motor terhadap berbagai kondisi dataran, pengujian GPS, dan pengujian arus menunjukkan bahwa robot dapat digunakan untuk memantau dan melakukan pembersihan sampah di pantai. Hasil pengujian menunjukkan bahwa robot dapat melaju sesuai dengan jalur yang ditentukan, sesuai koordinat yang dimasukan (akurasi 100\%) dan mampu mengangkut sampah plastik. Hal ini dikarenakan motor yang digunakan memiliki torsi kecil, sehingga tidak mampu mengangkat benda besar. Beberapa hal yang dapat dilakukan untuk pengembangan robot pembersih pantai selanjutnya adalh terkait: identifikasi kapasitas robot dalam menampung berbagai jenis sampah, uji coba kemampuan robot dalam melakukan pembersihan sampah, penggunaan sel surya, dan sistem manajemen lintasan.

\section{DAFTAR PUSTAKA}

[1] L. A. Pregiwati, "Laut masa depan bangsa, mari jaga bersama," Kementerian Kelautan dan Perikanan Republik Indonesia. Siaran Pers Nomor: SP204/SJ.04/VIII/2019, 2019. [Online]. Available: https://kkp.go.id/artikel/12993-lautmasa-depan-bangsa-mari-jaga-bersama.

[2] E. Roza, "Maritim Indonesia, Kemewahan Yang Luar Biasa," Kementerian Kelautan dan Perikanan Republik Indonesia, 2017. [Online]. Available: http://www2.kkp.go.id/artikel/2233maritim-indonesia-kemewahan-yang-luar-biasa.

[3] J. R. Jambeck, R. Geyer, C. Wilcox, T. R. Siegler, M. Perryman, A. Andrady, R. Narayan, and K. L. Law, "Plastic waste inputs from land intothe ocean," Science (80-. )., vol. 347, no. 6223, pp. 768-771, 2015. 
[4] W. Widyowati, A. R. Syaputri, and D. Febrianto, "Kebijakan Pemerintah Kota Denpasar terhadap Upaya Pencegahan Pencemaran Lingkungan Hidup di Kota Denpasar," J. Reformasi Huk. Cogito Ergo Sum, vol. 1, no. 2, pp. 45-50, 2018.

[5] S. N. Qodriyatun, Sampah plastik: dampaknya terhadap pariwisata dan solusi, vol. X, no. No. 23/I/Puslit/Desember/2018. Jakarta Pusat: Pusat Penelitian Badan Keahlian DPR RI, 2018.

[6] Sulisa, D. P. Safitri, and I. Y. Prastya, "Pengelolaan Sampah Berbasis Masyarakat di Wilayah Pesisir (Studi Kelurahan Pulau Penyengat)," Repos. Univ. Marit. Raja Ali Haji, pp. 1-19, 2018.

[7] K. Prakobkarna, B. Saitthitib, and S. Intaravichi, "Design and Construction of Beach Cleaning Trailer by Finite Element Method," Int. Trans. J. Eng. Manag. Appl. Sci. Technol., vol. 3, no. 2, pp. 111-123, 2012.

[8] S. Watanasophon and S. Ouitrakul, "Garbage Collection Robot on the Beach using Wireless Communications," in 3rd International Conference on Informatics, Environment, Energy and ApplicationsIPCBEE, 2014, vol. 66, pp. 92-96.

[9] A. Arun, P. Nagasankar, P. Amirthalingam, E. B. kumar. E, G. Janarthanan, and A. Magesh, "Design and Fabrication of Garbage Collector on the Beach Using Solar Power," Int. J. Eng. Technol., vol. 7, no. 3.34, pp. 394-396, 2018.

[10] A. K. Yadav, A. Singh, M. A. Murtaza, and A. K. Singh, "Eco Beach Cleaner," Int. J. Eng. Manag. Res., vol. 8, no. 3, pp. 1-4, 2018.
[11] V. Dhole, O. Doke, A. Kakade, S. Teradale, and R. Patil, "Design and fabrication of beach cleaning machine," Int. Res. J. Eng. Technol., vol. 6, no. 4, pp. 796-800, 2019.

[12]A. D. Team., "ArduPilot," ArduPilot: Versatile, Trusted, Open, 2019. [Online]. Available: https://ardupilot.org/ardupilot/index.html.

[13]ArduPilot Dev Team, "Mission Planner Overview," ArduPilot: Versatile, Trusted, Open, $2019 . \quad$ [Online]. Available: https://ardupilot.org/planner/docs/missionplanner-overview.html.

[14]A. D. Team., "Archived:APM 2.5 and 2.6 Overview," ArduPilot: Versatile, Trusted, Open, 2019. [Online]. Available: https://ardupilot.org/copter/docs/commonapm25-and-26-overview.html.

[15]G. T. Raber and S. R. Schill, "Reef Rover: A Low-Cost Small Autonomous Unmanned Surface Vehicle (USV) for Mapping and Monitoring Coral Reefs," Drones, vol. 3, no. 38, pp. 1-22, 2019.

[16] G. P. Cikarge and P. Utami, “Analisis dan Desain Media Pembelajaran Praktik Teknik Digital sesuai RPS," ELINVO(Electronics, Informatics, Vocat. Educ., vol. 3, no. 1, pp. 92-105, 2018.

[17] J. L. Pita and F. O. Saavedra, "UAV Trajectory Management: Ardupilot Based Trajectory Management System," in Proceedings - MDPI, 2019, vol. 21, no. 8, pp. 1-2. 